\title{
Trophic and neurotrophic factors in human pituitary adenomas (Review)
}

\author{
MARIALUISA SPOLETINI $^{*}$, SAMANTA TAURONE ${ }^{2 *}$, MARIO TOMBOLINI $^{2}$, \\ ANTONIO MINNI $^{2}$, GIANCARLO ALTISSIMI ${ }^{2}$, VENCESLAO WIERZBICKI ${ }^{3}$, \\ FELICE GIANGASPERO ${ }^{4,5}$, PIER PAOLO PARNIGOTTO ${ }^{6}$, MARCO ARTICO ${ }^{2}$, \\ LIA BARDELLA $^{7}$, ENZO AGOSTINELLI $^{8}$ and FRANCESCO SAVERIO PASTORE ${ }^{9}$ \\ Departments of ${ }^{1}$ Anatomy, Histology, Forensic Medicine and Orthopedics, and ${ }^{2}$ Sensory Organs, \\ 'Sapienza' University of Rome; ${ }^{3}$ Neurosurgery Department, Army Hospital of Rome 'Celio', Rome; \\ ${ }^{4}$ Department of Radiology, Oncology and Anatomic Pathology, 'Sapienza' University of Rome; \\ ${ }^{5}$ IRCCS Neuromed, Pozzilli (Is); ${ }^{6}$ Foundation for Biology and Regenerative Medicine, \\ Tissue Engineering and Signaling (TES) Onlus, Padua; Departments of ${ }^{7}$ Neurology and Psychiatry, \\ and ${ }^{8}$ Biochemical Sciences 'A. Rossi Fanelli', 'Sapienza' University of Rome; \\ ${ }^{9}$ Department of Systems' Medicine, Division of Neurosurgery, University of Rome 'Tor Vergata', Rome, Italy
}

Received March 23, 2017; Accepted July 17, 2017

DOI: $10.3892 /$ ijo.2017.4120

\begin{abstract}
The pituitary gland is an organ that functionally connects the hypothalamus with the peripheral organs. The pituitary gland is an important regulator of body homeostasis during development, stress, and other processes. Pituitary adenomas are a group of tumors arising from the pituitary gland: they may be subdivided in functional or non-functional, depending on their hormonal activity. Some trophic and neurotrophic factors seem to play a key role in the development and maintenance of the pituitary function and in the regulation of hypothalamo-pituitary-adrenocortical axis activity. Several lines of evidence suggest that trophic and neurotrophic factors may be involved in pituitary function, thus suggesting a possible role of the trophic and neurotrophic factors in the normal development of pituitary gland and in the progression of pituitary adenomas. Additional studies might be necessary to better explain the biological role of these molecules in the development and progression of this type of tumor. In this review, in light of the available literature, data on the following neurotrophic factors are discussed: ciliary neurotrophic factor (CNTF), transforming growth factors $\beta$ (TGF- $\beta$ ), glial cell line-derived neurotrophic factor (GDNF), nerve growth
\end{abstract}

Correspondence to: Professor Enzo Agostinelli, Department of Biochemical Sciences 'A. Rossi Fanelli', 'Sapienza' University of Rome, P.le Aldo Moro 5, I-00155 Rome, Italy

E-mail: enzo.agostinelli@uniroma1.it

${ }^{*}$ Contributed equally

Key words: pituitary gland, adenoma, trophic factors, neurotrophic factors, immunohistochemistry factor (NGF), vascular endothelial growth factor (VEGF), vascular endothelial growth inhibitor (VEGI), fibroblast growth factors (FGFs) and epidermal growth factor (EGF) which influence the proliferation and growth of pituitary adenomas.

\author{
Contents \\ 1. Introduction \\ 2. Ciliary neurotrophic factor (CNTF) \\ 3. Transforming growth factors $\beta$ (TGF- $\beta$ ) \\ 4. Glial cell line-derived neurotrophic factor (GDNF) \\ 5. Nerve growth factor (NGF) \\ 6. Vascular endothelial growth factor (VEGF) \\ 7. Vascular endothelial growth inhibitor (VEGI) \\ 8. Fibroblast growth factors (FGFs) \\ 9. Epidermal growth factor (EGF) \\ 10. Conclusion
}

\section{Introduction}

The pituitary gland is an organ that physiologically connects the hypothalamus with the peripheral organs. The pituitary gland is an important regulator of body homeostasis during development, stress, and other physiological processes. This small organ is localized in a tiny cavity called sella turcica. The pituitary fossa is a depression in the bone structure at the base of the brain.

The pituitary is functionally and anatomically connected to the hypothalamus by the median eminence. The gland receives blood through the hypophyseal portal circulation, which carries the hypothalamic hormones to the specialized adenohypophyseal cells. 
The pituitary gland is composed by adenohypophysis (or anterior pituitary) and neurohypophysis (or posterior pituitary) that are two different lobes. The adenohypophysis contains three regions: the pars tuberalis (pars infundibularis), the pars intermedia (intermediate lobe) and pars distalis (also known as the anterior lobe). The pars intermedia is placed in the marginal area between the anterior pituitary and the posterior pituitary. The pars distalis represents the largest part of the adenohypophysis while the intermediate lobe is a small portion of the gland. The different cells of pituitary gland secrete many molecules: endocrine hormones, cytokines and growth factors.

The neurohypophysis, or posterior pituitary, is characterized by axonal terminals of the hypothalamic supraoptic and paraventricular (PVN) nuclei. The neurohypophysis contains the pituicytes: fusiform cells related with microglia. The pituicytes surround the axons influencing the secretion of neurohypophyseal hormones (1) as oxytocin and vasopressin.

Hypothalamic stimulatory and inhibitory factors and other molecules interact with the auto- and paracrine factors to induce transcriptional regulation, translation and secretion of the pituitary hormones. Hormones released by the anterior pituitary are produced by specialized cells. Growth hormone $(\mathrm{GH})$ is produced by somatotroph, prolactin (PRL) by lactotrophs, adrenocorticotropic hormone (ACTH) by corticotrophs, thyroid-stimulating hormone (TSH) by thyreotrophs, luteinizing hormone (LH) and follicle-stimulating hormone (FSH) by gonadotrophs cells. The function of the specialized cells is influenced by the interaction between cells via systemic signals.

The lactotrophs are the cells located in the anterior pituitary and they interact with the gonadotrophs to improve the paracrine secretion. Gonadotrophs are in the pars distalis and tuberalis, while thyrotrophs, that represent a small section of the total pituitary cells, are found in the anterior-medial part of the pituitary gland and they secrete the subunits of PRL, LH, and FSH. In the central mucoid wedge of the pituitary gland, we can observe the presence of corticotrophs that constitute $15-20 \%$ of the adenophypophyseal cells (2). Folliculostellate cells (FS) represent a small rate of total population of pituitary cells. Some immunohistochemical studies described the presence of molecular connections between the FS cells in anterior gland $(3,4)$. FS cells in the normal pituitary tissue secrete large amounts of VEGF $(5,6)$ that improve blood vessel system of the gland (7).

The hypophysis may be affected by different pathologies causing endocrine and neurological disorders. Among these pathologies there are craniopharyngioma, pituicytoma and granular cell tumor, chordoma and the pituitary adenomas that are associated with endocrine dysfunctions such as Cushing's disease or acromegaly. Some pituitary neoplasms are simulated by pathological conditions as lymphocytic or granulomatous hypophysitis.

Craniopharyngiomas are relatively uncommon tumors and arise in the suprasellar region. They are believed to be congenital. Craniopharyngiomas involve the pituitary gland and they can modify the endocrine functions and damage optical nerves and chiasm, causing vision problems (8).

The pituicytoma is a rare neoplasm in the posterior pituitary gland that arises in the infundibulum or the neurohypophyseal cells. A possible development of this tumor was also noticed from the FS cells. In a recent study, a positivity for vascular endothelial growth factor (VEGF) was detected in patients with pituicytoma (9).

Granular cell tumors (GCTs) can arise in different regions of the body: skin, head and neck. GCTs occur rarely in the central nervous system developing in the posterior hypophysis and cerebral hemispheres $(10,11)$.

Intracranial chordomas are characterized by soft and gelatinous lesions usually developing at the dorsum sellae. The cells are large and vacuolated. Chordomas may produce compression of the pituitary and destruction of the pituitary fossa. These lesions slowly reach neurovascular bundles and often cannot be treated surgically (12).

Pituitary adenomas constitute a common group of benign tumors arising in adenohypophyseal cells of the anterior lobe of the pituitary gland $(13,14)$. Some adenomas are similar to malignant tumors, invading the cavernous sinus, sphenoid sinus and hypothalamus (15). The invasive adenomas are characterized by large size, rapid growth and scarce response to treatment. Pituitary adenomas may be subdivided to functional and non-functional, depending on their hormonal activity in vivo $(14,16,17)$.

Tumors may hypersecrete pituitary hormones which can determine endocrine disturbances of physiological mechanisms that are controlled by the gland. The pituitary adenomas can produce great doses of $\mathrm{GH}$ causing gigantism or acromegaly, ACTH leading to Cushing's disease and PRL, which negatively influences reproduction. Some very rare pituitary adenomas secrete $\mathrm{FSH}$ and $\mathrm{LH}$ (which cause reproductive dysfunction) or TSH that leads to hyperthyroidism. However, some pituitary tumors do not produce hormones, but their growth and expansion may produce a reduced function of the gland (hypopituitarism). Non-functioning pituitary adenomas represent $\sim 30 \%$ of all pituitary tumors (18). Non-functioning pituitary adenomas may be characterized by the feature of invasive macroadenomas that determine the onset of neurological symptoms (19).

Regarding the different therapeutic approaches, which include trans-sphenoidal resection, pharmacotherapy, and radiation therapy, the results remain inadequate in a significant number of patients $(20,21)$. The invasiveness of pituitary adenomas seems to be an important determinant for the success rate of surgical treatment. Generally, this tumor has no capsule that could separate it from the adjacent tissue and, consequently, the growing adenoma can reach and invade the adjacent structures (22). Such adenomas may produce some symptoms through two mechanisms: i) hypersecretion or hyposecretion of hormones and i) compression exerted on the neighbouring structures (23). Functioning pituitary adenomas become symptomatic because they lead to hormone secretion whereas the non-functioning variety may grow slowly and compress the optic chiasm situated directly above the pituitary gland, producing progressive visual loss (24).

Actually, the causes responsible for the pathogenic processes of initiation, expansion and invasion of pituitary tumors are not clear, but different mechanisms are involved in the pituitary tumorigenesis. A small percentage of tumors is hereditary and so these tumors may be due to genetic mutations (20). Recent studies suggest that neurotrophins and other 
Table I. List of abbreviations.

\begin{tabular}{llll}
\hline Adrenocorticotropic hormone & ACTH & Melanoma-associated antigen 3 & MAGEA3 \\
Protein kinase B & AKT & Mitogen-activated protein kinase & MAPK \\
Ciliary neurotrophic factor & CNTF & Nerve growth factor & NGF \\
Death receptor-3 & DR-3 & Nuclear factor $\mathrm{B} B$ & NF-kB \\
Decoy receptor-3 & DcR-3 & p75 neurotrophin receptor & p75NTR \\
Epidermal growth factor & EGF & Parkinson's disease & PD \\
Fibroblast growth factors & FGFs & Phosphatidyl inositol 3-kinase & PI3K \\
Follicle-stimulating hormone & FSH & Pituitary tumor-derived FGFR4 & Ptd-FGFR4 \\
Glial cell line-derived neurotrophic factor & GDNF & Prolactin & PRL \\
Glycosyl phosphatidyl inositol-linked protein & GFRa1 & Tropomyosin-related kinase A & TrkA \\
Granulocyte-macrofage colony-stimulating factor & GM-CSF & Tyrosine kinase receptor & RET \\
Growth hormone & GH & Signal transducer and activator of transcription & STAT \\
Human type- $\alpha$ transforming growth factor & hTGF- $\alpha$ & Small mother against dacapentaplegic & Smad \\
Interferon $\gamma$ & IFN- $\gamma$ & Thyroid-stimulating hormone & TSH \\
Janus kinases & JAK & Transforming growth factors $\beta$ & TGF- $\beta$ \\
Jun N-terminal kinase & JNK & Vascular endothelial growth factor & VEGF \\
Leukemia inhibitory factor receptor & LIFR & Vascular endothelial growth inhibitor & VEGI \\
Luteinizing hormone & LH & Vascular endothelial growth factor receptors & VEGFR \\
\hline
\end{tabular}

growth factors play a significant role in pituitary adenoma development (25-29) (Table I). In this review we summarize and discuss the data regarding the trophic and neurotrophic factors which seem to influence the proliferation and growth of pituitary adenomas.

\section{Ciliary neurotrophic factor (CNTF)}

The CNTF is a neurotrophin of the IL-6 family and has important neuroprotective effects on neurons. CNTF acts by binding to several receptors: CNTF receptor (CNTFR), gp130 and the leukemia inhibitory factor receptor (LIFR). The resultant CNTF-CNTFR $\alpha$ complex induces the formation of the LIFR $\alpha$-gp130 heterodimer. When CNTF interacts with the receptors it activates the Janus kinases/signal transducer and activator of transcription (JAK/STAT), mitogen-activated protein kinase (MAPK), and phosphatidyl inositol 3-kinase/ protein kinase B (PI3K/Akt) signalling pathways (30). Some studies found that the deletion of the CNTF gene in mice determines the degeneration of motor neurons and the increasing of an inflammatory demyelinating disease $(31,32)$. The CNTF have been demonstrated to be important for autocrine and paracrine mechanisms that act in the pituitary gland (33). CNTF is expressed in folliculostellate cells and in lactosomatotropic cells and its secretion stimulates the production of GH and PRL $(34,35)$.

Some authors observed that folliculostellate and lactosomatotrophic cells express the mRNA of CNTF (34) and the mRNA of the $\alpha$-chain specific for the CNTFR. This mRNA for the CNTFR was detected in tumors secreting PRL, GH and in non-functioning tumors (35). CNTFR are expressed on lactotropic, somatotropic and non-functioning pituitary adenomas demonstrating that these receptors are also present on human pituitary cells. CNTFR was seen to be involved in pituitary pathophysiology (35). In particular, CNTF did not influence the secretion of either GH or PRL and on GH mRNA in monolayer cell cultures obtained from normal rat anterior pituitary. However, CTNF significantly stimulated both PRL and GH secretion when the cells were amassed in cultures, restoring the three-dimensional structure of the cells. These results underline that the three-dimensional structure of the pituitary cells represents a key role for the regulatory action of CTNF in anterior pituitary cells (35). The three-dimensional organization of the cells constitutes their physiological conformation that can also result in a better expression of receptors. It was also observed that the interaction of hormone-secreting cells with the extracellular matrix is determining the role of $\mathrm{CNTF}$ in regulation of GH and PRL in producing the pituitary cells.

\section{Transforming growth factors $\beta$ (TGF- $\beta$ )}

TGF- $\beta$ is a suppressor or a promoter of tumor development in relation to the tumor stage and type $(25,36)$. TGF- $\beta$ signalling starts through the binding of some ligands (TGF- $\beta 1$, TGF- $\beta 2$ and TGF- $\beta 3$ ) with type II TGF- $\beta$ receptors (TGF- $\beta$ RII): subsequently the recruitment of type I TGF- $\beta$ receptor (TGF- $\beta$ RI) forms a complex (37-39). Moreover, TGF- $\beta$ RII phosphorylates TGF- $\beta$ RI to activate it (37-39). TGF- $\beta$ signal transducer proteins are Smads and the activated TGF- $\beta$ receptor complexes can phosphorylate Smad2 and Smad3. These proteins bind Smad4 to form a complex that regulates the transcriptional activity. On the other hand, Smad7 is an inhibitory protein that suppresses the phosphorylation of Smad 2 and Smad3 (40-42). Some authors reported that Smad3 and phospho-Smad3 are potential markers of invasive nonfunctioning pituitary adenomas. In particular, it was observed that the invasion of non-functioning pituitary adenoma is 
associated with low level of expression of Smad3 and phosphoSmad3 and that proliferative activity was higher in invasive non-functioning pituitary adenomas when compared to noninvasive non-functioning pituitary adenomas (43).

The clinical importance of TGF- $\beta$ ligands and downstream signalling mediators has been analyzed in some studies performed in different types of tumors although the results obtained are discordant (37-39). In non-functioning pituitary adenomas, the expression of mRNA TGF- $\beta 1$ levels was significantly lower than in invasive non-functioning pituitary adenomas and in non-invasive non-functioning pituitary adenomas, in comparison to normal anterior pituitaries (43). It has been suggested that the invasiveness of pituitary adenomas could be predicted by TGF- $\beta 1$ blood serum concentration (44). Some studies widely evaluated the role of the TGF- $\beta 1$ gene in some tumors. The expression of this gene was studied in subjects with breast cancer and a relationship was found between TGF- $\beta 1$ gene and a poorer patient clinical outcome (45). The evaluation of a tumor in lung cell lines, established that this gene plays an important role in cell proliferation (46). TGF- $\beta 1$ is commonly evaluated in tumors: in fact, the in vitro studies were performed on TGF- $\beta 1$ function in cancer cell lines other than lung cancer and pituitary adenoma cells (47).

A study described the development of prolactinomas in transgenic female mice with pituitary TGF- $\alpha$ transgene expression (48). The levels of pituitary TGF- $\alpha$ mRNA become high before initiation of lactotroph hyperplasia. TGF effects are increased in vivo conditions by estrogen, and TGFs do not seem to improve other pituitary cell type cancers.

\section{Glial cell line-derived neurotrophic factor (GDNF)}

GDNF is a component of a large family of neurotrophic factors that include GDNF, Neurturin, Artemin, and Persephin $(49,50)$. GDNF plays a crucial role in the development and survival of various neuronal populations $(51,52)$. However, the intracellular trafficking mechanisms of GDNF are not fully understood. Some studies demonstrated that although GDNF is not essential for the development of dopaminergic neurons $(49,50)$, the presence of GDNF is important for the maintenance of these cells in A9 dopaminergic neurons of tyrosine kinase receptor (RET) knockout mice (51). In fact, degeneration of A9 neurons is evident in Parkinson's disease (PD) and GDNF was retained to be a possible therapeutic drug for PD. The signalling of GDNF is mediated through a system including GFRal which binds to GDNF. Subsequently, this complex binds and triggers the RET $(52,53)$. Recently, GDNF and RET gene expression have been found in anterior pituitary glands from male rats (54). In an interesting study, a positive immunostaining for GDNF was observed in all of the GH-secreting pituitary adenomas and in $10 \%$ of the corticotropinomas (55). Some experimental evaluations showed that both RET and GDNF are normally secreted in the human pituitary gland. These results were confirmed through other experimental techniques, demonstrating that the pituitary gland produces GDNF and that the gland itself is also a target tissue of neurotrophins (55). GDNF is mostly present in somatotrophs and, to a lesser extent, in corticotrophs, but it is not present in gonadotrophs of the human pituitary gland (55). In particular, a positive immunostaining for GDNF was observed in all of the GH secreting adenomas and in $10 \%$ of the corticotropinomas, but it was negative in all other pituitary tumors.

\section{Nerve growth factor (NGF)}

NGF is a growth factor expressed by peripheral tissues that are innervated by sensory and sympathetic neuronal projections and it belongs to the nerve growth factor family of neurotrophins. NGF controls neuronal survival, differentiation and growth binding to two receptors: the p75 neurotrophin receptor (p75NTR) and tropomyosin-related kinase A (TrkA) (56-58). Some studies have demonstrated that NGF is involved in tumor progression, increasing cancer cell survival and proliferation (59-61). NGF is not only described in the nervous system, but also in some normal and neoplastic human tissues $(62,63)$. In the submandibular gland of the mouse NGF is composed of $2 \alpha$ subunits, $1 \beta$ subunit, $2 \gamma$ subunits $(\alpha 2 \beta \gamma 2)$ and also one or two zinc ions (64). The $\beta$ subunit of NGF represents a biologically active region, the $2 \gamma$ subunits of NGF have proteolytic activity and the $2 \alpha$ subunits do not possess enzymatic activity (65-67).

NGF acts as a regulator of neuronal survival, proliferation, and differentiation in the peripheral and central nervous systems by binding to its receptors: TrkA and p75NTR. The binding between p75NTR and NGF controls the activation of c-Jun N-terminal kinase (JNK) signalling pathways to promote apoptosis, and the activation of nuclear factor $\kappa \mathrm{B}(\mathrm{NF}-\kappa \mathrm{B})$ pathways to promote cell survival. Moreover, NGF increases cell proliferation and metastasis binding to $\operatorname{TrkA}(68,69)$. Some researchers have also found that p75NTR may help to improve the binding of NGF with TrkA, TrkA activation and the number of binding sites (70). TrkA regulates growth and differentiation of neurons in peripheral and central nervous systems (71). NGF facilitates the development of perivascular nerves to regulate the blood flow in tumors. NGF may promote angiogenesis by interacting with $\alpha 9 \beta 1$ integrin (72). In one study it was observed that p75NTR in tumor cells may negatively regulate cell growth and proliferation (73). An increased apoptosis (pro-apoptotic effect) was demonstrated in cells with a high expression of p75NTR from patients with medulloblastoma (74). In prolactinoma cells, NGF binds p75NTR and activates $\mathrm{NF}-\kappa \mathrm{B}$ in a TrkA-independent way (75). It was observed that TrkA triggers proliferation in some tumor cells $(76,77)$, but inhibits cell growth in other tumors $(78,79)$. In some patients with pituitary adenomas, a moderate expression for NGF, and its relative receptor TrKA and p75NTR were observed on epithelial glands (29) (Fig. 1). It has also been found that p75NTR suppresses some tumors $(80,81)$, but has a mitogenic effect in others (82). The cell cycle controls the cell proliferation and the G1 phase of the cycle is regulated by the protein p53 that is a tumor suppressor (83). Inactivation of this pathway influences tumorigenesis. Some mutations that inactivate the p53 gene are observed in more than $50 \%$ of all human cancers (84). However, p53 is rarely mutated in human pituitary adenomas (85). Mammosomatotroph pituitary cells express NGF and its receptors. Mice, in which transgenic NGF is driven by the prolactin promoter, develop lactotroph hyperplasia without adenomas, despite having markedly enlarged pituitary glands (86). 

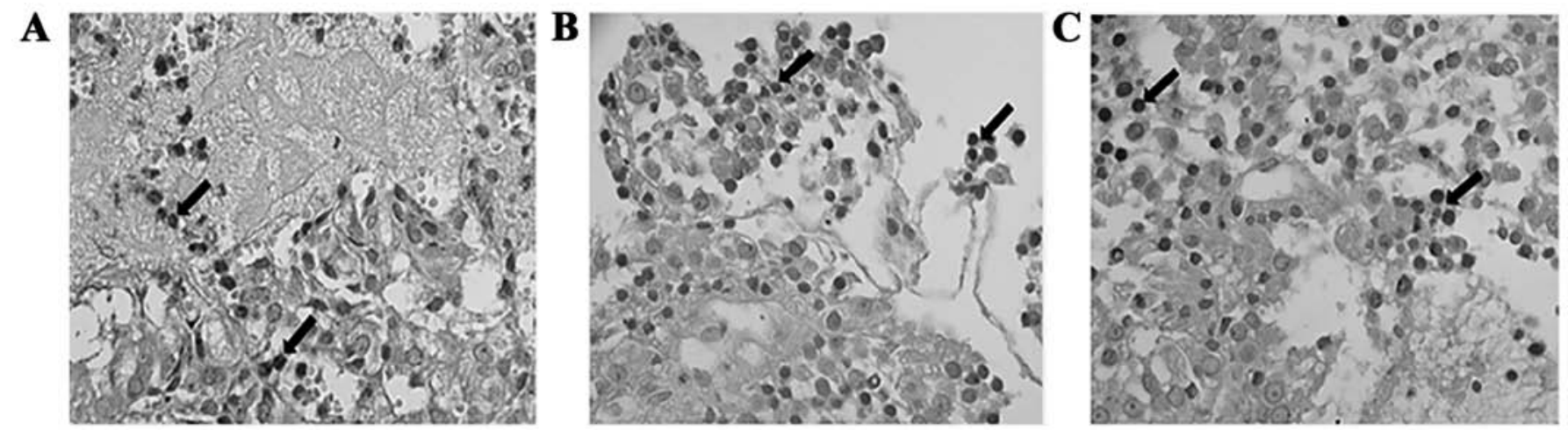

Figure 1. (A) Micrographs of NGF-TrKA-P75 immunostaining in GH-secreting pituitary adenomas. NGF immunoreactivity was moderate (arrows) in the epithelial compartment of the neoplastic area, weak in the extracellular matrix and totally absent in the vessel endothelium (x40). (B) P75NTR immunoreactivity was weak (arrows) in the epithelial neoplastic cells and in the extracellular matrix, but totally absent in the vessel endothelium (x40). (C) Immunoreaction for TrKA was moderate in the nucleus of the neoplastic cells (arrows), weak in the extracellular matrix and totally absent in the vessel endothelium (x40).

\section{Vascular endothelial growth factor (VEGF)}

VEGF is a central regulatory protein of angiogenesis with a hydrophobic leader sequence. It has a homodimeric structure with three intramolecular and two intermolecular disulfide (S-S) bonds. It is a member of a family that exerts important functions in vasculogenesis, angiogenesis and lymphangiogenesis. It was found that VEGF is a tumor-secreted protein that can increase microvascular permeability to plasma proteins. In particular, it improves vascular permeability to plasma and plasma proteins, a typical characteristic of the tumor microvasculature and a critical early step in cancer stroma generation. VEGF is overexpressed in the cells of several human vascular tumors of the brain, colon, gastrointestinal tract, ovary, and breast (87). Some studies found that VEGF may not directly participate to tumoral invasion, but it may regulate pathways that increase tumor volume or invasiveness (88-91). Results obtained in a study, described that VEGF operates as a neurotrophic factor and plays an important role during the regeneration of peripheral nerves (92).

VEGF binds and activates the type 1 and 2 vascular endothelial growth factor receptors (VEGFR1 and VEGFR2) on the vascular endothelium (93). In the pituitary VEGF and VEGFR2 are expressed $(94,95)$. Various experimental publications reported that VEGF expression is not necessarily related to endothelium and vessels, but it is also found in adenoma cells $(28,96)$. Distribution and location of VEGF receptors in pituitary adenomas has also been studied. A relevant expression of fetal liver kinase-1, a type of VEGF receptor that controls mitogenesis and influences endothelial cell characteristics, may have a potential role in the pituitary tumorigenesis (97). According to this observation fetal liver kinase-1 expression was very marked in non-functioning adenomas in comparison to functioning tumors (97). Other reports concerning the expression and the distribution of VEGF and its receptors in pituitary adenomas are not conclusive. In another study, VEGF expression was recognized as different in the subtypes, thus suggesting possible different modalities of VEGF expression and/or effects (28). The tyrosine kinase receptors of VEGF are mainly expressed on vascular endothelium, and it behaves as a selective mitogen for vascular endothelium.
VEGF contributes to the formation of the vascular network of a new pituitary tumor $(98,99)$ and is also involved in the proliferative action of estrogen on lactotrophs (100), VEGF might contribute to adequate temporal vascular supply. It was observed that VEGF is expressed in all cell types of the pituitary, but mainly in somatotrophic and follicle-stellate cells. In the normal human pituitary gland, VEGF expression was higher than adenomas (28). One study found no differences in VEGF expression among tumors of different histotypes (101). Also, comparing VEGF in different types, the highest expression was observed in non-functioning adenomas and GH producing adenomas (97). Elevated serum VEGF levels have been determined in patients with pituitary tumors and VEGF secretion was measured in human pituitary tumors cultured in vitro. In a group of patients with pituitary adenomas it was observed that VEGF protein expression was higher in dopamine agonist resistant prolactinomas compared to non-functioning GH and ACTH secreting adenomas (102). Different VEGF levels in ACTH-secreting adenomas may be produced by glucocorticoids which are efficient inhibitors of VEGF secretion (103). VEGF targeting in pituitary adenomas may be useful as shown in a study performed on mice (104).

The VEGF is characterized from several variants of the growth factor that can bind one of the three VEGF-specific receptor tyrosine kinases to influence angiogenesis or related processes (105). The VEGF secretion is increased by hypoxia of the tumor. The deficiency of oxygen increases the expression of hypoxia-inducible factor 1 (HIF1), which enhances the VEGF expression.

\section{Vascular endothelial growth inhibitor (VEGI)}

VEGI is a protein member of the TNF superfamily that can inhibit the proliferation of endothelial cells and exerts an antiangiogenic effect on the endothelial cells (106). VEGI is mainly produced by vessel endothelial cells and also be expressed on antigen-presenting cells and lymphocytes such as T cells and dendritic cells. VEGI always acts as a co-stimulator to induce $\mathrm{T}$ cell proliferation and cytokine secretion $(107,108)$. VEGI acts by interacting with two receptors: death receptor-3 (DR-3) and the decoy receptor-3 (DcR-3). DR-3 is also known as 


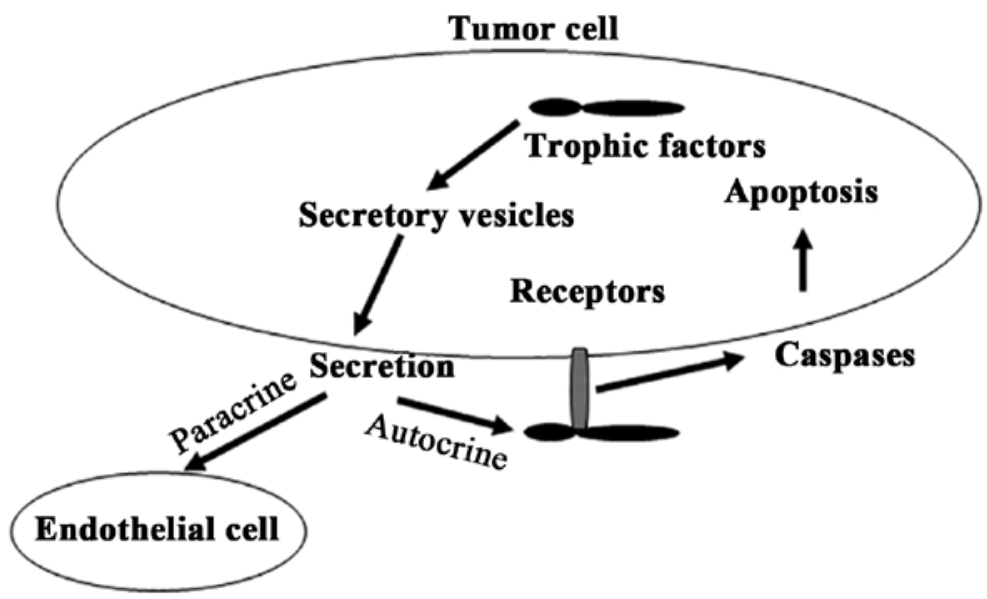

Neoangiogenesis

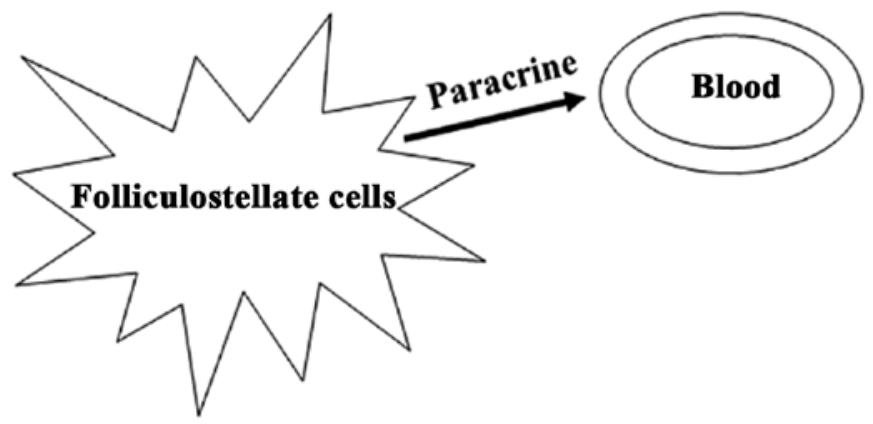

Figure 2. Autocrine and paracrine secretion of trophic factors and their influence on intracellular and extracellular compartments.

TNFRSF25: this receptor is a protein of approximate $47 \mathrm{kDa}$ in size and is a member of the TNF receptor superfamily. So far DR3 is the only known functional receptor for VEGI and its role is to induce apoptosis after activation.

Many studies have shown that VEGI is related to various diseases including bowel diseases (109), lung cancer (110), prostate cancer (111), breast cancer (112) and pituitary adenomas (27). The authors of these studies described how VEGI expression is decreased in late stage tumors and is associated with survival of patients. VEGI and other factors may influence the development of diseases through the involvement of some pathways (Fig. 2). It was recently found that VEGI has a direct effect on both epithelial and cancer cells, also by exerting an inhibitory effect on the migration and growth of neoplastic cells. Some results indicated that VEGI plays an essential role in activating the transcription factor $\kappa \mathrm{B}$ and caspase-3 (113). Other studies suggested that VEGI may also be involved in the immune response by inducing the secretion of granulocyte-macrofage colony-stimulating factor (GM-CSF) and interferon $\gamma$ IFN- $\gamma$ (114). VEGI gene expression also decreases inflammation and angiogenesis in cancers or wounds (114). Studies that involved the cell cycle suggested that VEGI maintained early G1 arrest in the G0/G1 cells and induced programmed death in the endothelial cell cycle (115).

Pituitary tumors with cystic lesions tended to express low levels of VEGI and, in particular, pituitary tumors that invade the floor of the sella turcica showed reduced levels of VEGI. VEGI has an anti-angiogenesis function and some studies demonstrated that it acts as a powerful angiogenesis inhibitor. Lack of VEGI was negatively correlated with angiogenesis in solid tumors, due to the removal of the inhibitory mechanisms in the tissues $(116,117)$. In pituitary adenomas, VEGI inhibits the growth and the migration of tumor cells through DR3 (113). In particular, high levels of VEGI and DR3 were found to be associated with intratumoral haemorrhage. It is thus argued that, in a similar pattern, the lack of VEGI in pituitary tumors may trigger an increase in angiogenesis within the tumor tissues.

\section{Fibroblast growth factors (FGFs)}

FGFs are a family of molecules that control the differentiation, migration, and angiogenesis of the cells $(118,119)$. FGFs includes 23 ligands and FGF2 is the basic FGF, which regulates the production of pituitary hormones and the proliferation and differentiation of parenchyma and vessels (120). FGF2 isoform of $18 \mathrm{kDa}$ is highly secreted in the normal human pituitary gland, whereas the $24 \mathrm{kDa}$ isoform is largely secreted by pituitary adenomas (121). It was observed that high levels of FGF2 were expressed in patients with pituitary neoplasms and the secretion decreased after surgical adenomectomy (122). In a recent study, it was found that FGF2 is secreted in different types of pituitary tumors, including $\mathrm{GH}$ secreting adenomas (123). FGF2 expression was significantly higher in patients without postoperative remission observed at the third month and later, if compared to subjects with remission (123). Also, the levels of FGF2 were higher in patients who presented a sphenoid bone invasion if compared to patients without bony lesions (123).

The interaction between FGF2 and some transmembrane receptors (FGFRs) with tyrosine kinase activity, determines the biological effects of FGF2 (124). The FGFRs are encoded 
by different genes to obtain multiple isoforms, also the FGFRs are expressed in the membrane surfaces of different type of cells, including endothelial cells in which FGF2 influences the angiogenic development. Each FGFR is characterized by three Ig-like extracellular domains, a transmembrane domain, a tyrosine kinase cytoplasmic domain and a - $\mathrm{COOH}$ domain that comprehends a group of tyrosines phosphorylated by the binding with the ligand $(125,126)$. A great percentage of FGFs shows a specific affinity for the receptor isoforms. It was observed that FGFRs are expressed in different types of tumors, including pituitary adenomas (127-132). In particular, FGFR1 was highly expressed in pituitary adenomas compared to healthy gland (132) and the cytoplasmic immunoreactivity of the receptor was inversely correlated with pituitary lesion size (133).

A study has demonstrated the lack of FGFR2 in the pituitary adenomas that causes the upregulation of the melanoma-associated antigen 3 (MAGEA3) (134). The presence of arginine at codon 388 of the FGFR4 gene, which encodes the receptor, was associated with the phosphorylation process of mitochondrial STAT3 serine that improves the GH secretion in pituitary cells promoting tumorigenesis development (135). Also, this arginine allele was associated with other forms of tumors resistant to the pharmacological treatment (136-139). The expression of FGFR isoforms was really modified in pituitary adenomas (140). It was observed that the modified FGFR4 expression in pituitary tumors is caused by the pituitary tumor-derived FGFR4 (ptd-FGFR4) (141). This is an isoform with a deletion at the N-terminal produced by substitute transcription initiation $(141,142)$. The FGFR4 isoforms have a different capability to link the cell adhesion molecules and, in particular, ptd-FGFR4 blocks cell adhesion interacting with N-cadherin signaling (143). The complex constituted by FGFR4 and N-cadherin may be considered an important therapeutic target to reduce the growth and the invasiveness of tumor cells (143).

\section{Epidermal growth factor (EGF)}

EGF is a small protein of $6 \mathrm{kDa}$ containing 53 amino acids which comprises three disulfide bridges (144). EGF displays a homology of function and sequence with human type- $\alpha$ transforming growth factor (hTGF- $\alpha$ ), which can link the EGF receptor sites. EGF is characterized by mitogenic activity and so it is involved in the process of cell growth and tumorigenesis. In fact, EGF is a protein contained in a network of growth factors and receptors that controls the growth and the division of cells. EGF is produced by pituitary cells and it acts as a growth factor, stimulating prolactin synthesis (145). In human pituitary gland EGF is localized mainly in thyrotrophic and gonadotrophic cells (145). An immunohistochemical study described the EGF expression in functional and non-functional pituitary adenomas (145).

It was observed that EGF can promote the transphosphorylation of the related oncogene neu through the binding with epidermal growth factor receptor (EGF-R) (146). EGF-R is a $170-\mathrm{kDa}$ transmembrane glycoprotein constituted by: a tyrosine kinase domain, a transmembrane domain and an extracellular domain of binding. EFG- $R$ is a component of a family which includes four known members and it is considered the homolog of the v-erbB oncogene protein (147). Some studies evidenced EGF-R overexpression in different tumors: lung (148), breast (149), ovarian (150) and gastric (151) cancers. Different studies observed a higher expression in non-functional pituitary tumors (152-154). Interestingly, Onguru et al described a moderate or a strong positivity of EGFR in more than $50 \%$ of adenomas (154). In each group of adenomas the percentage of EGFR overexpression was variable and it was higher in non-functional compared to functional adenomas.

Also, in ACTH secreting adenomas the lowest number of tumors expressing EGFR was detected (154). However, high expression of EGFR is frequently found in ACTH secreting adenomas, in which EGF signaling is deleted and consequently there is inhibition of ACTH secretion $(155,156)$. The binding between intracellular EGFR domain and its specific antibody showed an immunoreactivity in corticotroph adenomas and many cells of ACTH secreting tumors were EGFR immunoreactive (157). Also, a low or absent immunoreactivity was observed for p27 protein that blocks the cell cycle (157). Probably, EGFR promotes the signaling activation that induces the downregulation of $\mathrm{p} 27$, which promotes tumorigenesis by the stimulation of ACTH secretion (158).

\section{Conclusion}

Pituitary adenomas are common tumors that are classified on the basis of certain characteristics: size, invasion of adjacent structures, sporadic or familial cases, biochemical activity, clinical manifestations, morphological characteristics, response to treatment and recurrence. Although they are considered benign tumors, some of them are difficult to treat because they can recur after standardized treatment. Some studies indicate that trophic and neurotrophic factors play a significant role in neuroendocrine systems and in the biological effects of molecules involved in the development and maintenance of the nervous system. There is some evidence suggesting that trophic and neurotrophic factors may be involved in pituitary endocrine cell function, suggesting a possible role of trophic and neurotrophic factors in the normal development of the pituitary gland and in the progression of some pituitary adenomas.

The pituitary cells are regulated by endocrine and paracrine systems through the action of some growth factors and their receptors. A different expression and action of these factors and their receptors may determine the development and progression of pituitary tumors. The vascularization in the normal pituitary regulates the growth of pituitary cells and the hormone secretion by some molecules: hormones, hypothalamic and pituitary growth factors. However, the high secretion of EGF, FGF and VEGF in pituitary is involved in gland tumorigenesis (159). Generally, the pituitary adenomas have a low grade of carcinogenicity. In fact, these tumors are rarely aggressive and the angiogenesis is not predominantly involved in the improvement of the release of nutrients to the tumor. Basing upon these reasons, it may be interesting to study the possible role of VEGF involved in pituitary angiogenesis. The development of the vascularization in pituitary tumors is less present than in the normal anterior pituitary tissue $(160,161)$.

The biological role of these factors in the development and progression of this type of tumor should be further investigated 
to ameliorate the knowledge of the pathogenesis of pituitary adenomas.

\section{Acknowledgements}

This study was supported by Nobile S.p.A. Grant from REGIONE LAZIO Prot. FILAS-RU-2014-1020 is gratefully acknowledged (EA).

\section{References}

1. Rosso L and Mienville JM: Pituicyte modulation of neurohormone output. Glia 57: 235-243, 2009.

2. Doniach I: Histopathology of the pituitary. Clin Endocrinol Metab 14: 765-789, 1985

3. Chauvet N, El-Yandouzi T, Mathieu MN, Schlernitzauer A Galibert E, Lafont C, Le Tissier P, Robinson IC, Mollard P and Coutry N: Characterization of adherens junction protein expression and localization in pituitary cell networks. J Endocrinol 202: 375-387, 2009.

4. Stojilkovic SS: A novel view of the function of pituitary folliculostellate cell network. Trends Endocrinol Metab 12: 378-380, 2001.

5. Cristina C, Díaz-Torga G, Baldi A, Góngora A, Rubinstein M, Low MJ and Becú-Villalobos D: Increased pituitary vascular endothelial growth factor-a in dopaminergic D2 receptor knockout female mice. Endocrinology 146: 2952-2962, 2005.

6. Alfer J, Neulen J and Gaumann A: Lactotrophs: The new and major source for VEGF secretion and the influence of ECM on rat pituitary function in vitro. Oncol Rep 33: 2129-2134, 2015.

7. Chauvet N, Romanò N, Lafont $\mathrm{C}$, Guillou $\mathrm{A}$, Galibert $\mathrm{E}$, Bonnefont X, Le Tissier P, Fedele M, Fusco A, Mollard P, et al Complementary actions of dopamine D2 receptor agonist and anti-vegf therapy on tumoral vessel normalization in a transgenic mouse model. Int J Cancer 140: 2150-2161, 2017.

8. Hoffmann A, Boekhoff S, Gebhardt U, Sterkenburg AS, Daubenbüchel AM, Eveslage M and Müller HL: History before diagnosis in childhood craniopharyngioma: Associations with initial presentation and long-term prognosis. Eur J Endocrinol 173: 853-862, 2015

9. Mende KC, Matschke J, Burkhardt T, Saeger W, Buslei R, Buchfelder M, Fahlbusch R, Westphal M and Flitsch $J$ Pituicytoma-An outlook on possible targeted therapies. CNS Neurosci Ther 23: 620-626, 2017.

10. Li P, Yang Z, Wang Z, Zhou Q, Li S, Wang X, Wang B, Zhao F and Liu P: Granular cell tumors in the central nervous system: A report on eight cases and a literature review. Br J Neurosurg 30 611-618, 2016.

11. Mumert ML, Walsh MT, Chin SS and Couldwell WT: Cystic granular cell tumor mimicking Rathke cleft cyst. J Neurosurg 114 325-328, 2011

12. Larkin S and Ansorge O: Pathology and pathogenesis of pituitary adenomas and other sellar lesions. Endotext [Internet]. De Groot LJ, Chrousos G, Dungan K, Feingold KR, Grossman A, Hershman JM, Koch C, Korbonits M, McLachlan R, New M, Purnell J, Rebar R, Singer F and Vinik A (eds). MDText.com, Inc. 2000, South Dartmouth, MA, 2017.

13. Ezzat S, Asa SL, Couldwell WT, Barr CE, Dodge WE, Vance ML and McCutcheon IE: The prevalence of pituitary adenomas: A systematic review. Cancer 101: 613-619, 2004.

14. Asa SL: Tumors of the pituitary gland. In: Atlas of Tumor Pathology Rosai J (ed). 3rd series Fascicle 22. Armed Forces Institute of Pathology (AFIP), Washington DC, pp1-214, 1998.

15. Blevins LS Jr, Verity DK and Allen G: Aggressive pituitary tumors. Oncology (Williston Park) 12: 1307-1312, 1315, discussion $1315-1318,1998$.

16. Asa SL and Ezzat S: The pathogenesis of pituitary tumours. Nat Rev Cancer 2: 836-849, 2002.

17. Nammour GM, Ybarra J, Naheedy MH, Romeo JH and Aron DC: Incidental pituitary macroadenoma: A population-based study. Am J Med Sci 314: 287-291, 1997.

18. Katznelson L, Alexander JM and Klibanski A: Clinical review 45: Clinically nonfunctioning pituitary adenomas. J Clin Endocrinol Metab 76: 1089-1094, 1993.

19. Colao A, Di Somma C, Pivonello R, Faggiano A, Lombardi G and Savastano S: Medical therapy for clinically non-functioning pituitary adenomas. Endocr Relat Cancer 15: 905-915, 2008.
20. Daly AF, Tichomirowa MA and Beckers A: The epidemiology and genetics of pituitary adenomas (Review). Best Pract Res Clin Endocrinol Metab 23: 543-554, 2009.

21. Galland F, Lacroix L, Saulnier P, Dessen P, Meduri G, Bernier M, Gaillard S, Guibourdenche J, Fournier T, Evain-Brion D, et al: Differential gene expression profiles of invasive and non-invasive non-functioning pituitary adenomas based on microarray analysis. Endocr Relat Cancer 17: 361-371, 2010.

22. Syro LV, Rotondo F, Ramirez A, Di Ieva A, Sav MA, Restrepo LM, Serna CA and Kovacs K: Progress in the diagnosis and classification of pituitary adenomas. Front Endocrinol (Lausanne) 6: 97 2015.

23. Kovacs K, Scheithauer BW, Horvath E and Lloyd RV: The World Health Organization classification of adenohypophysial neoplasms. A proposed five-tier scheme. Cancer 78: 502-510, 1996.

24. Jagannathan J, Dumont AS, Prevedello DM, Lopes B, Oskouian RJ, Jane JA Jr and Laws ER Jr: Genetics of pituitary adenomas: Current theories and future implications. Neurosurg Focus 19: E4, 2005.

25. Wakefield LM and Roberts AB: TGF-beta signaling: Positive and negative effects on tumorigenesis. Curr Opin Genet Dev 12: 22-29, 2002.

26. Massagué J: TGFbeta in cancer (Review). Cell 134: 215-230, 2008.

27. Jia W, Sander AJ, Jia G, Ni M, Liu X, Lu R and Jiang WG: Vascular endothelial growth inhibitor (VEGI) is an independent indicator for invasion in human pituitary adenomas. Anticancer Res 33: 3815-3822, 2013.

28. Lloyd RV, Scheithauer BW, Kuroki T, Vidal S, Kovacs K and Stefaneanu L: Vascular endothelial growth factor (VEGF) expression in human pituitary adenomas and carcinomas. Endocr Pathol 10: 229-235, 1999.

29. Artico M, Bianchi E, Magliulo G, De Vincentiis M, De Santis E, Orlandi A, Santoro A, Pastore FS, Giangaspero F, Caruso R, et al: Neurotrophins, their receptors and KI-67 in human GH-secreting pituitary adenomas: An immunohistochemical analysis. Int J Immunopathol Pharmacol 25: 117-125, 2012.

30. Ernst $\mathrm{M}$ and Jenkins BJ: Acquiring signalling specificity from the cytokine receptor gp130. Trends Genet 20: 23-32, 2004.

31. Masu Y, Wolf E, Holtmann B, Sendtner M, Brem G and Thoenen H: Disruption of the CNTF gene results in motor neuron degeneration. Nature 365: 27-32, 1993.

32. Linker RA, Mäurer M, Gaupp S, Martini R, Holtmann B, Giess R, Rieckmann P, Lassmann H, Toyka KV, Sendtner M, et al: CNTF is a major protective factor in demyelinating CNS disease: A neurotrophic cytokine as modulator in neuroinflammation. Nat Med 8: 620-624, 2002.

33. Ray D and Melmed S: Pituitary cytokine and growth factor expression and action. Endocr Rev 18: 206-228, 1997.

34. Perez Castro C, Nagashima AC, Pereda MP, Goldberg V, Chervin A, Largen P, Renner U, Stalla GK and Arzt E: The gp130 cytokines interleukin-11 and ciliary neurotropic factor regulate through specific receptors the function and growth of lactosomatotropic and folliculostellate pituitary cell lines. Endocrinology 141: 1746-1753, 2000.

35. Perez Castro C,Carbia Nagashima A, Páez Pereda M, Goldberg V, Chervin A, Carrizo G, Molina H, Renner U, Stalla GK and Arzt E: Effects of the gp130 cytokines ciliary neurotropic factor (CNTF) and interleukin-11 on pituitary cells: CNTF receptors on human pituitary adenomas and stimulation of prolactin and GH secretion in normal rat anterior pituitary aggregate cultures. J Endocrinol 169: 539-547, 2001.

36. Yang L, Pang Y and Moses HL: TGF-beta and immune cells: An important regulatory axis in the tumor microenvironment and progression. Trends Immunol 31: 220-227, 2010.

37. Johnson MD, Shaw AK, O'Connell MJ, Sim FJ and Moses HL: Analysis of transforming growth factor $\beta$ receptor expression and signaling in higher grade meningiomas. J Neurooncol 103: 277-285, 2011

38. Bruna A, Darken RS, Rojo F, Ocaña A, Peñuelas S, Arias A, Paris R, Tortosa A, Mora J, Baselga J, et al: High TGFbeta-Smad activity confers poor prognosis in glioma patients and promotes cell proliferation depending on the methylation of the PDGF-B gene. Cancer Cell 11: 147-160, 2007.

39. Wu Y, Li Q, Zhou X, Yu J, Mu Y, Munker S, Xu C, Shen Z, Müllenbach R, Liu Y, et al: Decreased levels of active SMAD2 correlate with poor prognosis in gastric cancer. PLoS One 7: e35684, 2012.

40. Massagué J: TGF $\beta$ signalling in context. Nat Rev Mol Cell Biol 13: 616-630, 2012. 
41. Heldin $\mathrm{CH}$, Miyazono $\mathrm{K}$ and ten Dijke P: TGF-beta signalling from cell membrane to nucleus through SMAD proteins. Nature 390: 465-471, 1997.

42. Nakao A, Afrakhte M, Morén A, Nakayama T, Christian JL, Heuchel R, Itoh S, Kawabata M, Heldin NE, Heldin CH, et al: Identification of Smad7, a TGFbeta-inducible antagonist of TGF-beta signalling. Nature 389: 631-635, 1997.

43. Liu C, Li Z, Wu D, Li C and Zhang Y: Smad3 and phosphoSmad 3 are potential markers of invasive nonfunctioning pituitary adenomas. Onco Targets Ther 9: 2265-2271, 2016.

44. Elenkova A, Atanassova I, Kirilov G, Vasilev V, Kalinov K and Zacharieva S: Transforming growth factor $\beta 1$ is not a reliable biomarker for valvular fibrosis but could be a potential serum marker for invasiveness of prolactinomas (pilot study). Eur J Endocrinol 169: 299-306, 2013.

45. Chen C, Zhao KN, Masci PP, Lakhani SR, Antonsson A, Simpson PT and Vitetta L: TGF $\beta$ isoforms and receptors mRNA expression in breast tumours: Prognostic value and clinical implications. BMC Cancer 15: 1010, 2015.

46. Liu ZY, Zhang GL, Wang MM, Xiong YN and Cui HQ: MicroRNA-663 targets TGFB1 and regulates lung cancer proliferation. Asian Pac J Cancer Prev 12: 2819-2823, 2011.

47. Wang Y, Jiang M, Li Z, Wang J, Du C, Yanyang L, Yu Y, Wang X, Zhang N, Zhao M, et al: Hypoxia and TGF- $\beta 1$ lead to endostatin resistance by cooperatively increasing cancer stem cells in A549 transplantation tumors. Cell Biosci 5: 72, 2015.

48. McAndrew J, Paterson AJ, Asa SL, McCarthy KJ and Kudlow JE: Targeting of transforming growth factor-alpha expression to pituitary lactotrophs in transgenic mice results in selective lactotroph proliferation and adenomas. Endocrinology 136: 4479-4488, 1995.

49. Airaksinen MS, Titievsky A and Saarma M: GDNF family neurotrophic factor signaling: Four masters, one servant? Mol Cell Neurosci 13: 313-325, 1999.

50. Airaksinen MS and Saarma M: The GDNF family: Signalling, biological functions and therapeutic value. Nat Rev Neurosci 3 : 383-394, 2002

51. Kramer ER, Aron L, Ramakers GM, Seitz S, Zhuang X, Beyer K, Smidt MP and Klein R: Absence of Ret signaling in mice causes progressive and late degeneration of the nigrostriatal system. PLoS Biol 5: e39, 2007.

52. Treanor JJ, Goodman L, de Sauvage F, Stone DM, Poulsen KT Beck CD, Gray C, Armanini MP, Pollock RA, Hefti F, et al: Characterization of a multicomponent receptor for GDNF. Nature 382: 80-83, 1996.

53. Robertson $\mathrm{K}$ and Mason I: The GDNF-RET signalling partnership. Trends Genet 13: 1-3, 1997.

54. Urbano AG, Suárez-Peñaranda JM, Diéguez C and Alvarez CV: GDNF and RET-gene expression in anterior pituitary-cell types. Endocrinology 141: 1893-1896, 2000.

55. Japón MA, Urbano AG, Sáez C, Segura DI, Cerro AL, Diéguez C and Alvarez CV: Glial-derived neurotropic factor and RET gene expression in normal human anterior pituitary cell types and in pituitary tumors. J Clin Endocrinol Metab 87: 1879-1884, 2002.

56. Lykissas MG, Batistatou AK, Charalabopoulos KA and Beris AE: The role of neurotrophins in axonal growth, guidance, and regeneration. Curr Neurovasc Res 4: 143-151, 2007.

57. Cui X, Chen L, Ren Y, Ji Y, Liu W, Liu J, Yan Q, Cheng L and Sun YE: Genetic modification of mesenchymal stem cells in spinal cord injury repair strategies. Biosci Trends 7: 202-208, 2013.

58. Wiesmann C and de Vos AM: Nerve growth factor: Structure and function. Cell Mol Life Sci 58: 748-759, 2001.

59. Mancino M, Ametller E, Gascón P and Almendro V: The neuronal influence on tumor progression. Biochim Biophys Acta 1816: 105-118, 2011

60. Krüttgen A, Schneider I and Weis J: The dark side of the NGF family: Neurotrophins in neoplasias. Brain Pathol 16: 304-310, 2006.

61. Molloy NH, Read DE and Gorman AM: Nerve growth factor in cancer cell death and survival. Cancers (Basel) 3: 510-530, 2011.

62. MacGrogan D, Saint-André JP and Dicou E: Expression of nerve growth factor and nerve growth factor receptor genes in human tissues and in prostatic adenocarcinoma cell lines. J Neurochem 59: 1381-1391, 1992.

63. Vanhecke E, Adriaenssens E, Verbeke S, Meignan S, Germain E, Berteaux N, Nurcombe V, Le Bourhis X and Hondermarck H: Brain-derived neurotrophic factor and neurotrophin-4/5 are expressed in breast cancer and can be targeted to inhibit tumor cell survival. Clin Cancer Res 17: 1741-1752, 2011.
64. Varon S, Nomura J and Shooter EM: The isolation of the mouse nerve growth factor protein in a high molecular weight form. Biochemistry 6: 2202-2209, 1967.

65. Thoenen $\mathrm{H}$ and Barde YA: Physiology of nerve growth factor Physiol Rev 60: 1284-1335, 1980.

66. Fahnestock M, Yu G, Michalski B, Mathew S, Colquhoun A, Ross GM and Coughlin MD: The nerve growth factor precursor proNGF exhibits neurotrophic activity but is less active than mature nerve grow th factor. J Neurochem 89: 581-592, 2004.

67. Seidel MF, Herguijuela M, Forkert R and Otten U: Nerve growth factor in rheumatic diseases. Semin Arthritis Rheum 40: 109-126, 2010.

68. Masoudi R, Ioannou MS, Coughlin MD, Pagadala P, Neet KE, Clewes O, Allen SJ, Dawbarn D and Fahnestock M: Biological activity of nerve growth factor precursor is dependent upon relative levels of its receptors. J Biol Chem 284: 18424-18433, 2009.

69. Haase G, Pettmann B, Raoul C and Henderson CE: Signaling by death receptors in the nervous system. Curr Opin Neurobiol 18: 284-291, 2008.

70. Barker PA: High affinity not in the vicinity? Neuron 53: 1-4, 2007.

71. Nakagawara A: Trk receptor tyrosine kinases: A bridge between cancer and neural development. Cancer Lett 169: 107-114, 2001

72. Walsh EM, Kim R, Del Valle L, Weaver M, Sheffield J, Lazarovici $P$ and Marcinkiewicz C: Importance of interaction between nerve growth factor and $\alpha 9 \beta 1$ integrin in glial tumor angiogenesis. Neuro-oncol 14: 890-901, 2012.

73. Reis-Filho JS, Steele D, Di Palma S, Jones RL, Savage K, James M, Milanezi F, Schmitt FC and Ashworth A: Distribution and significance of nerve growth factor receptor (NGFR/ p75NTR) in normal, benign and malignant breast tissue. Mod Pathol 19: 307-319, 2006.

74. Küchler J, Hartmann W, Waha A, Koch A, Endl E, Wurst P, Kindler D, Mikeska T, Waha A, Goodyer CG, et al: p75(NTR) induces apoptosis in medulloblastoma cells. Int J Cancer 128: 1804-1812, 2011

75. Fiorentini C, Guerra N, Facchetti M, Finardi A, Tiberio L, Schiaffonati L, Spano P and Missale C: Nerve growth factor regulates dopamine $\mathrm{D}(2)$ receptor expression in prolactinoma cell lines via p75(NGFR)-mediated activation of nuclear factorkappaB. Mol Endocrinol 16: 353-366, 2002.

76. Descamps S, Toillon RA, Adriaenssens E, Pawlowski V, Cool SM, Nurcombe V, Le Bourhis X, Boilly B, Peyrat JP and Hondermarck $\mathrm{H}$ : Nerve growth factor stimulates proliferation and survival of human breast cancer cells through two distinct signaling pathways. J Biol Chem 276: 17864-17870, 2001.

77. Sortino MA, Condorelli F, Vancheri C, Chiarenza A, Bernardini R, Consoli U and Canonico PL: Mitogenic effect of nerve growth factor (NGF) in LNCaP prostate adenocarcinoma cells: Role of the high- and low-affinity NGF receptors. Mol Endocrinol 14: 124-136, 2000.

78. Hughes AL, Gollapudi L, Sladek TL and Neet KE: Mediation of nerve growth factor-driven cell cycle arrest in PC12 cells by p53. Simultaneous differentiation and proliferation subsequent to p53 functional inactivation. J Biol Chem 275: 37829-37837, 2000.

79. Decker SJ: Nerve growth factor-induced growth arrest and induction of $\mathrm{p} 21 \mathrm{Cip1/WAF} 1$ in NIH-3T3 cells expressing TrkA. J Biol Chem 270: 30841-30844, 1995.

80. Krygier S and Djakiew D: Neurotrophin receptor p75(NTR) suppresses growth and nerve growth factor-mediated metastasis of human prostate cancer cells. Int J Cancer 98: 1-7, 2002.

81. Khwaja F and Djakiew D: Inhibition of cell-cycle effectors of proliferation in bladder tumor epithelial cells by the p75NTR tumor suppressor. Mol Carcinog 36: 153-160, 2003.

82. Weis C, Wiesenhofer B and Humpel C: Nerve growth factor plays a divergent role in mediating growth of rat C6 glioma cells via binding to the p75 neurotrophin receptor. J Neurooncol 56: 59-67, 2002.

83. Zilfou JT and Lowe SW: Tumor suppressive functions of p53. Cold Spring Harb Perspect Biol 1: a001883, 2009.

84. Rivlin N, Brosh R, Oren M and Rotter V: Mutations in the p53 tumor suppressor gene: Important milestones at the various Steps of tumorigenesis. Genes Cancer 2: 466-474, 2011.

85. Tanizaki Y, Jin L, Scheithauer BW, Kovacs K, Roncaroli F and Lloyd RV: P53 gene mutations in pituitary carcinomas. Endocr Pathol 18: 217-222, 2007. 
86. Borrelli E, Sawchenko PE and Evans RM: Pituitary hyperplasia induced by ectopic expression of nerve growth factor. Proc Natl Acad Sci USA 89: 2764-2768, 1992.

87. Ferrara $\mathrm{N}$ and Davis-Smyth T: The biology of vascular endothelial growth factor (Review). Endocr Rev 18: 4-25, 1997.

88. Fukui S, Nawashiro H, Otani N, Ooigawa H, Yano A, Nomura N, Tokumaru AM, Miyazawa T, Ohnuki A, Tsuzuki N, et al: Vascular endothelial growth factor expression in pituitary adenomas. Acta Neurochir (Suppl) 86: 519-521, 2003.

89. Niveiro M, Aranda FI, Peiró G, Alenda C and Picó A Immunohistochemical analysis of tumor angiogenic factors in human pituitary adenomas. Hum Pathol 36: 1090-1095, 2005.

90. Pan LX, Chen ZP, Liu YS and Zhao JH: Magnetic resonance imaging and biological markers in pituitary adenomas with invasion of the cavernous sinus space. J Neurooncol 74: 71-76, 2005.

91. Arita K, Kurisu K, Tominaga A, Sugiyama K, Eguchi K, Hama S, Yoshioka H, Yamasaki F and Kanou Y: Relationship between intratumoral hemorrhage and overexpression of vascular endothelial growth factor (VEGF) in pituitary adenoma. Hiroshima J Med Sci 53: 23-27, 2004.

92. Sondell M, Sundler F and Kanje M: Vascular endothelial growth factor is a neurotrophic factor which stimulates axonal outgrowth through the flk-1 receptor. Eur J Neurosci 12: 4243-4254, 2000.

93. Maeda K, Chung YS, Takatsuka S, Ogawa Y, Sawada T, Yamashita Y, Onoda N, Kato Y, Nitta A and Arimoto Y: Tumor angiogenesis as a predictor of recurrence in gastric carcinoma. J Clin Oncol 13: 477-481, 1995.

94. Ochoa AL, Mitchner NA, Paynter CD, Morris RE and Ben-Jonathan N: Vascular endothelial growth factor in the rat pituitary: Differential distribution and regulation by estrogen. J Endocrinol 165: 483-492, 2000.

95. Vidal S, Lloyd RV, Moya L, Scheithauer BW and Kovacs K: Expression and distribution of vascular endothelial growth factor receptor Flk-1 in the rat pituitary. J Histochem Cytochem 50: 533-540, 2002.

96. Yamada S and Takada K: Angiogenesis in pituitary adenomas. Microsc Res Tech 60: 236-243, 2003.

97. McCabe CJ, Boelaert K, Tannahill LA, Heaney AP, Stratford AL, Khaira JS, Hussain S, Sheppard MC, Franklyn JA and Gittoes NJ: Vascular endothelial growth factor, its receptor KDR/Flk-1, and pituitary tumor transforming gene in pituitary tumors. J Clin Endocrinol Metab 87: 4238-4244, 2002.

98. Banerjee SK, Zoubine MN, Tran TM, Weston AP and Campbell DR: Overexpression of vascular endothelial growth factor164 and its co-receptor neuropilin-1 in estrogen-induced rat pituitary tumors and $\mathrm{GH} 3$ rat pituitary tumor cells. Int J Oncol 16: 253-260, 2000.

99. Kim K, Yoshida D and Teramoto A: Expression of hypoxiainducible factor 1alpha and vascular endothelial growth factor in pituitary adenomas. Endocr Pathol 16: 115-121, 2005.

100. Onofri C, Carbia Nagashima A, Schaaf L, Feirer M, Lohrer P, Stummer W, Berner S, Chervin A, Goldberg V, Stalla GK, et al: Estradiol stimulates vascular endothelial growth factor and interleukin- 6 in human lactotroph and lactosomatotroph pituitary adenomas. Exp Clin Endocrinol Diabetes 112: 18-23, 2004.

101. Viacava P, Gasperi M, Acerbi G, Manetti L, Cecconi E, Bonadio AG, Naccarato AG, Acerbi F, Parenti G, Lupi I, et al: Microvascular density and vascular endothelial growth factor expression in normal pituitary tissue and pituitary adenomas. J Endocrinol Invest 26: 23-28, 2003.

102. Cristina C, Perez-Millan MI, Luque G, Dulce RA, Sevlever G, Berner SI and Becu-Villalobos D: VEGF and CD31 association in pituitary adenomas. Endocr Pathol 21: 154-160, 2010.

103. Lohrer P, Gloddek J, Hopfner U, Losa M, Uhl E, Pagotto U, Stalla GK and Renner U: Vascular endothelial growth factor production and regulation in rodent and human pituitary tumor cells in vitro. Neuroendocrinology 74: 95-105, 2001.

104. Korsisaari N, Ross J, Wu X, Kowanetz M, Pal N, Hall L, Eastham-Anderson J, Forrest WF, Van Bruggen N, Peale FV, et al: Blocking vascular endothelial growth factor-A inhibits the growth of pituitary adenomas and lowers serum prolactin level in a mouse model of multiple endocrine neoplasia type 1 . Clin Cancer Res 14: 249-258, 2008.

105. Fowkes RC and Vlotides G: Hypoxia-induced VEGF production 'RSUMEs' in pituitary adenomas. Endocr Relat Cancer 19: C1-C5, 2012.
106.Zhai Y, Ni J, Jiang GW, Lu J, Xing L, Lincoln C, Carter KC, Janat F, Kozak D, Xu S, et al: VEGI, a novel cytokine of the tumor necrosis factor family, is an angiogenesis inhibitor that suppresses the growth of colon carcinomas in vivo. FASEB J 13: 181-189, 1999.

107. Prehn JL, Thomas LS, Landers CJ, Yu QT, Michelsen KS and Targan SR: The T cell costimulator TL1A is induced by FcgammaR signaling in human monocytes and dendritic cells J Immunol 178: 4033-4038, 2007.

108. Migone TS, Zhang J, Luo X, Zhuang L, Chen C, Hu B, Hong JS, Perry JW, Chen SF, Zhou JX, et al: TL1A is a TNF-like ligand for DR3 and TR6/DcR3 and functions as a T cell costimulator. Immunity 16: 479-492, 2002.

109. Bamias G, Martin C III, Marini M, Hoang S, Mishina M, Ross WG, Sachedina MA, Friel CM, Mize J, Bickston SJ, et al: Expression, localization, and functional activity of TL1A, a novel Th1-polarizing cytokine in inflammatory bowel disease. J Immunol 171: 4868-4874, 2003.

110. Liang PH, Tian F, Lu Y, Duan B, Stolz DB and Li LY: Vascular endothelial growth inhibitor (VEGI; TNFSF15) inhibits bone marrow-derived endothelial progenitor cell incorporation into Lewis lung carcinoma tumors. Angiogenesis 14: 61-68, 2011

111. Zhang N, Sanders AJ, Ye L, Kynaston HG and Jiang WG: Vascular endothelial growth inhibitor, expression in human prostate cancer tissue and the impact on adhesion and migration of prostate cancer cells in vitro. Int J Oncol 35: 1473-1480, 2009.

112. Parr C, Gan $\mathrm{CH}$, Watkins $\mathrm{G}$ and Jiang WG: Reduced vascular endothelial growth inhibitor (VEGI) expression is associated with poor prognosis in breast cancer patients. Angiogenesis 9: 73-81, 2006.

113. Haridas V, Shrivastava A, Su J, Yu GL, Ni J, Liu D, Chen SF, Ni Y, Ruben SM, Gentz R, et al: VEGI, a new member of the TNF family activates nuclear factor-kappa B and c-Jun $\mathrm{N}$-terminal kinase and modulates cell growth. Oncogene 18: 6496-6504, 1999.

114. Lu Y, Gu X, Chen L, Yao Z, Song J, Niu X, Xiang R, Cheng T, Qin Z, Deng W, et al: Interferon- $\gamma$ produced by tumor-infiltrating NK cells and $\mathrm{CD}^{+}{ }^{+} \mathrm{T}$ cells downregulates TNFSF15 expression in vascular endothelial cells. Angiogenesis 17: 529-540, 2014.

115. Yu J, Tian S, Metheny-Barlow L, Chew LJ, Hayes AJ, Pan H, Yu GL and Li LY: Modulation of endothelial cell growth arrest and apoptosis by vascular endothelial growth inhibitor. Circ Res 89: 1161-1167, 2001.

116. Kaptein A, Jansen M, Dilaver G, Kitson J, Dash L, Wang E, Owen MJ, Bodmer JL, Tschopp J and Farrow SN: Studies on the interaction between TWEAK and the death receptor WSL-1/ TRAMP (DR3). FEBS Lett 485: 135-141, 2000.

117. Locksley RM, Killeen $\mathrm{N}$ and Lenardo MJ: The TNF and TNF receptor superfamilies: Integrating mammalian biology. Cell 104: 487-501, 2001.

118. Gospodarowicz D, Jones KL and Sato G: Purification of a growth factor for ovarian cells from bovine pituitary glands. Proc Natl Acad Sci USA 71: 2295-2299, 1974.

119. Ezzat S, Zheng L and Asa SL: Pituitary tumor-derived fibroblast growth factor receptor 4 isoform disrupts neural cell-adhesion molecule/N-cadherin signaling to diminish cell adhesiveness: A mechanism underlying pituitary neoplasia. Mol Endocrinol 18: 2543-2552, 2004

120. Gospodarowicz D, Ferrara N, Schweigerer L and Neufeld G: Structural characterization and biological functions of fibroblast growth factor. Endocr Rev 8: 95-114, 1987.

121. Li Y, Koga M, Kasayama S, Matsumoto K, Arita N, Hayakawa T and Sato B: Identification and characterization of high molecular weight forms of basic fibroblast growth factor in human pituitary adenomas. J Clin Endocrinol Metab 75: 1436-1441, 1992.

122. Zimering MB, Katsumata N, Sato Y, Brandi ML, Aurbach GD, Marx SJ and Friesen HG: Increased basic fibroblast growth factor in plasma from multiple endocrine neoplasia type 1: Relation to pituitary tumor. J Clin Endocrinol Metab 76: 1182-1187, 1993.

123. Ozkaya HM, Comunoglu N, Keskin FE, Oz B, Haliloglu OA, Tanriover N, Gazioglu N and Kadioglu P: Locally produced estrogen through aromatization might enhance tissue expression of pituitary tumor transforming gene and fibroblast growth factor 2 in growth hormone-secreting adenomas. Endocrine 52: 632-640, 2016. 
124. Moscatelli D: High and low affinity binding sites for basic fibroblast growth factor on cultured cells: Absence of a role for low affinity binding in the stimulation of plasminogen activator production by bovine capillary endothelial cells. J Cell Physiol 131: 123-130, 1987.

125. Givol D and Yayon A: Complexity of FGF receptors: Genetic basis for structural diversity and functional specificity. FASEB J 6: 3362-3369, 1992.

126. Qian ZR, Sano T, Asa SL, Yamada S, Horiguchi H, Tashiro T, Li CC, Hirokawa M, Kovacs K and Ezzat S: Cytoplasmic expression of fibroblast growth factor receptor-4 in human pituitary adenomas: Relation to tumor type, size, proliferation, and invasiveness. J Clin Endocrinol Metab 89: 1904-1911, 2004

127. Jaakkola S, Salmikangas P, Nylund S, Partanen J, Armstrong E, Pyrhönen S, Lehtovirta P and Nevanlinna H: Amplification of fgfr4 gene in human breast and gynecological cancers. Int J Cancer 54: 378-382, 1993.

128. Ohta T, Yamamoto M, Numata M, Iseki S, Tsukioka Y, Miyashita T, Kayahara M, Nagakawa T, Miyazaki I, Nishikawa K, et al: Expression of basic fibroblast growth factor and its receptor in human pancreatic carcinomas. Br J Cancer 72 824-831, 1995.

129. Ahmed NU, Ueda M, Ito A, Ohashi A, Funasaka Y and Ichihashi M: Expression of fibroblast growth factor receptors in naevus-cell naevus and malignant melanoma. Melanoma Res 7: 299-305, 1997.

130. Giri D, Ropiquet $\mathrm{F}$ and Ittmann $\mathrm{M}$ : Alterations in expression of basic fibroblast growth factor (FGF) 2 and its receptor FGFR-1 in human prostate cancer. Clin Cancer Res 5: 1063-1071, 1999.

131. Henriksson ML, Edin S, Dahlin AM, Oldenborg PA, Öberg À, Van Guelpen B, Rutegård J, Stenling R and Palmqvist R: Colorectal cancer cells activate adjacent fibroblasts resulting in FGF1/FGFR3 signaling and increased invasion. Am J Pathol 178: 1387-1394, 2011

132. McCabe CJ, Khaira JS, Boelaert K, Heaney AP, Tannahill LA, Hussain S, Mitchell R, Olliff J, Sheppard MC, Franklyn JA, et al: Expression of pituitary tumour transforming gene (PTTG) and fibroblast growth factor-2 (FGF-2) in human pituitary adenomas: Relationships to clinical tumour behaviour. Clin Endocrinol (Oxf) 58: 141-150, 2003.

133. Fukui S, Otani N, Nawashiro H, Yano A, Nomura N, Miyazawa T, Ohnuki A, Tsuzuki N, Katoh H, Ishihara S, et al Subcellular localization of basic fibroblast growth factor and fibroblast growth factor receptor 1 in pituitary adenomas. Brain Tumor Pathol 19: 23-29, 2002

134. Zhu X, Asa SL and Ezzat S: Fibroblast growth factor 2 and estrogen control the balance of histone 3 modifications targeting MAGE-A3 in pituitary neoplasia. Clin Cancer Res 14: 1984-1996, 2008.

135. Tateno T, Asa SL, Zheng L, Mayr T, Ullrich A and Ezzat S: The FGFR4-G388R polymorphism promotes mitochondrial STAT3 serine phosphorylation to facilitate pituitary growth hormone cell tumorigenesis. PLoS Genet 7: e1002400, 2011.

136. da Costa Andrade VC, Parise O Jr, Hors CP, de Melo Martins PC Silva AP and Garicochea B: The fibroblast growth factor receptor 4 (FGFR4) Arg388 allele correlates with survival in head and neck squamous cell carcinoma. Exp Mol Pathol 82: 53-57, 2007.

137. Frullanti E, Berking C, Harbeck N, Jézéquel P, Haugen A, Mawrin C, Parise O Jr, Sasaki H, Tsuchiya N and Dragani TA: Meta and pooled analyses of FGFR4 Gly388Arg polymorphism as a cancer prognostic factor. Eur J Cancer Prev 20: 340-347, 2011.

138. Serra S, Zheng L, Hassan M, Phan AT, Woodhouse LJ, Yao JC, Ezzat S and Asa SL: The FGFR4-G388R single-nucleotide polymorphism alters pancreatic neuroendocrine tumor progression and response to mTOR inhibition therapy. Cancer Res 72 5683-5691, 2012

139. Marmé F, Werft W, Benner A, Burwinkel B, Sinn P, Sohn C, Lichter P, Hahn M and Schneeweiss A: FGFR4 Arg388 genotype is associated with pathological complete response to neoadjuvant chemotherapy for primary breast cancer. Ann Oncol 21: 1636-1642, 2010.

140. Abbass SA, Asa SL and Ezzat S: Altered expression of fibroblast growth factor receptors in human pituitary adenomas. J Clin Endocrinol Metab 82: 1160-1166, 1997.

141. Ezzat S, Zheng L, Zhu XF, Wu GE and Asa SL: Targeted expression of a human pituitary tumor-derived isoform of FGF receptor-4 recapitulates pituitary tumorigenesis. J Clin Invest 109: 69-78, 2002.
142. Ezzat S, Yu S and Asa SL: Ikaros isoforms in human pituitary tumors: Distinct localization, histone acetylation, and activation of the 5' fibroblast growth factor receptor-4 promoter. Am J Pathol 163: 1177-1184, 2003.

143. Ezzat S, Zheng L, Winer D and Asa SL: Targeting N-cadherin through fibroblast growth factor receptor-4: Distinct pathogenetic and therapeutic implications. Mol Endocrinol 20: 2965-2975, 2006.

144. Fisher DA and Lakshmanan J: Metabolism and effects of epidermal growth factor and related growth factors in mammals (Review). Endocr Rev 11: 418-442, 1990.

145. Murdoch GH, Potter E, Nicolaisen AK, Evans RM and Rosenfeld MG: Epidermal growth factor rapidly stimulates prolactin gene transcription. Nature 300: 192-194, 1982.

146. Qian X, LeVea CM, Freeman JK, Dougall WC and Greene MI: Heterodimerization of epidermal growth factor receptor and wild-type or kinase-deficient Neu: A mechanism of interreceptor kinase activation and transphosphorylation. Proc Natl Acad Sci USA 91: 1500-1504, 1994.

147. Downward J, Yarden Y, Mayes E, Scrace G, Totty N, Stockwell P, Ullrich A, Schlessinger J and Waterfield MD: Close similarity of epidermal growth factor receptor and v-erb-B oncogene protein sequences. Nature 307: 521-527, 1984.

148. Bethune G, Bethune D, Ridgway N and Xu Z: Epidermal growth factor receptor (EGFR) in lung cancer: An overview and update. J Thorac Dis 2: 48-51, 2010.

149. Nicholson S, Richard J, Sainsbury C, Halcrow P, Kelly P, Angus B, Wright C, Henry J, Farndon JR and Harris AL: Epidermal growth factor receptor (EGFr); results of a 6 year follow-up study in operable breast cancer with emphasis on the node negative subgroup. Br J Cancer 63: 146-150, 1991.

150. Hudson LG, Zeineldin R, Silberberg M and Stack MS: Activated epidermal growth factor receptor in ovarian cancer. Cancer Treat Res 149: 203-226, 2009.

151. Takehana T, Kunitomo K, Suzuki S, Kono K, Fujii H, Matsumoto Y and Ooi A: Expression of epidermal growth factor receptor in gastric carcinomas. Clin Gastroenterol Hepatol 1: 438-445, 2003.

152. LeRiche VK, Asa SL and Ezzat S: Epidermal growth factor and its receptor (EGF-R) in human pituitary adenomas: EGF-R correlates with tumor aggressiveness. J Clin Endocrinol Metab 81: 656-662, 1996.

153. Chaidarun SS, Eggo MC, Sheppard MC and Stewart PM: Expression of epidermal growth factor (EGF), its receptor, and related oncoprotein (erbB-2) in human pituitary tumors and response to EGF in vitro. Endocrinology 135: 2012-2021, 1994.

154. Onguru O, Scheithauer BW, Kovacs K, Vidal S, Jin L, Zhang S, Ruebel KH and Lloyd RV: Analysis of epidermal growth factor receptor and activated epidermal growth factor receptor expression in pituitary adenomas and carcinomas. Mod Pathol 17: 772-780, 2004

155. Fukuoka H, Cooper O, Ben-Shlomo A, Mamelak A, Ren SG, Bruyette D and Melmed S: EGFR as a therapeutic target for human, canine, and mouse ACTH-secreting pituitary adenomas. J Clin Invest 121: 4712-4721, 2011.

156. Vallar L, Spada A and Giannattasio G: Altered Gs and adenylate cyclase activity in human $\mathrm{GH}$-secreting pituitary adenomas. Nature 330: 566-568, 1987.

157. Theodoropoulou M, Arzberger T, Gruebler Y, Jaffrain-Rea ML, Schlegel J, Schaaf L, Petrangeli E, Losa M, Stalla GK and Pagotto U: Expression of epidermal growth factor receptor in neoplastic pituitary cells: Evidence for a role in corticotropinoma cells. J Endocrinol 183: 385-394, 2004

158. Theodoropoulou M, Reincke M, Fassnacht M and Komada M: Decoding the genetic basis of Cushing's disease: USP8 in the spotlight. Eur J Endocrinol 173: M73-M83, 2015.

159. Yu R and Melmed S: Pathogenesis of pituitary tumors. Prog Brain Res 182: 207-227, 2010

160. Onofri C, Theodoropoulou M, Losa M, Uhl E, Lange M, Arzt E, Stalla GK and Renner U: Localization of vascular endothelial growth factor (VEGF) receptors in normal and adenomatous pituitaries: Detection of a non-endothelial function of VEGF in pituitary tumours. J Endocrinol 191: 249-261, 2006.

161. Turner HE, Nagy Z, Gatter KC, Esiri MM, Harris AL and Wass JA: Angiogenesis in pituitary adenomas and the normal pituitary gland. J Clin Endocrinol Metab 85: 1159-1162, 2000. 